\title{
TOWARD TORT LIABILITY FOR BAD SAMARITANS
}

\author{
ALLEN LINDEN ${ }^{*}$
}

\begin{abstract}
Good Samaritan laws are common throughout Canada and the United States. The rationale for the development of Good Samaritans law has been that the benefit of immunity for Good Samaritans is more altruistic than the punishment of liability for Bad Samaritans. However, our tort law's declaration that one need not assist one in danger weakens the moral stature of our law. Our law supports those who do the right thing and denounces those who do the wrong thing. The intrusiveness of liability for bystanders is usually argued against Bad Samaritan laws. However potential liability is rare; the moral stature of our law is worth the effort to resolve this issue.
\end{abstract}

For more than a century now, tort scholars have disagreed over the way tort law should treat Good Samaritans and Bad Samaritans. Every law student learned in first year that there was no duty on a Bad Samaritan to assist someone in danger, even though this principle was generally condemned by scholars as "shocking," "revolting," "repugnant," "cruel," "selfish," "inhuman," and "immoral." Paradoxically, the Good Samaritan, who selflessly undertook to assist someone in danger, might be held partially liable if he or she did so negligently. Over the years, almost all Canadian provinces and American states have rightly rectified this unacceptable paradox through legislation by completely or partly immunizing Good Samaritans from liability. However, somehow, Bad Samaritans have been largely left alone, immune from any liability, except in a handful of jurisdictions. I plan to address what I consider the unfinished business of tort law, that of no tort liability for Bad Samaritans. ${ }^{1}$

Over one hundred years ago, in an early 1908 address to the Cincinnati Law School, James Barr Ames, the reforming Dean of the Harvard Law School, urged the adoption of a "working rule" to the effect that "[o]ne who fails to interfere to save another from impending death or great bodily harm, when he might do so with little or no inconvenience to himself, and the death or great bodily harm follows as a consequence of his inaction, shall be punished criminally and shall make compensation to the party injured or the widow and children in case of death."2

In April of the same year, the great Francis Bohlen of the University of Pennsylvania, later to become the Reporter of the Restatement (First) of Torts, ${ }^{3}$ advanced a fundamentally contrary view. Without acknowledging the "Law and Morals" article of Dean Ames, which was not actually published until December of 1908 though it was delivered orally earlier,

The Honourable Allen Linden, OC, QC, retired Justice of the Federal Court of Appeal. I would like to thank Shirley Margolis of LexisNexis Canada for her superb contribution to the preparation of this article.

I know full well that Lewis Klar will disagree strenuously with me on this issue, as he always has. See Lewis N Klar, Tort Law, 5th ed (Toronto, Ont: Carswell, 2012); Allen M Linden \& Bruce Feldthusen, Canadian Tort Law, 10th ed (Markham: LexisNexis Canada, 2015).

2 James Barr Ames, "Law and Morals" (1908) 22:2 Harv L Rev 97 at 113, delivered orally in late 1907 or early 1908. I will focus on the role of tort law in this matter, although penal law is usually also involved.

3 Restatement (First) of Torts (1934) [First Restatement]. 
Professor Bohlen declared with great clarity and confidence what he felt was the accepted principle of tort law, which many believe holds sway even today:

There is no distinction more deeply rooted in the common law and more fundamental than that between misfeasance and non-feasance, between active misconduct working positive injury to others and passive in action, a failure to take positive steps to benefit others, or to protect them from harm not created by any wrongful act of the defendant. ${ }^{4}$

Consequently, in his view, no common law duty could be owed to aid anyone in danger without some particular additional relationship existing between them.

There is no doubt that, of these two titans of torts, Professor Bohlen triumphed in this “pseudo-debate." His article was far more thorough and specific than Dean Ames' article, consisting of 51 pages and copious footnotes, whereas Dean Ames' piece was more general, lightly footnoted, and comprised only 17 pages. The Ames speech was not footnoted in the Bohlen article at all, and the article had not yet been published. Nevertheless, there is an enigmatic footnote in the Bohlen article referring to "J.B. Ames in Harvard L.R.," without mention of any speech, article title, volume number, or page number. This leads me to think that, as Bohlen was writing his article, he learned about the Ames speech and that it would soon be published in the Harvard Law Review, even though it was not published until December 1908, after Bohlen's article appeared in the University of Pennsylvania Law Review. Therefore, in my view, Bohlen was responding indirectly to the Ames piece, reflecting his opposition to Ames' proposed "working rule," without attacking it expressly, because it had not yet appeared in print.

Many years later, in preparing the Restatement of Torts as Reporter, Professor Bohlen, true to his view of the law, drafted section 314, which was adopted in 1934 as follows:

Duties of Affirmative Action: Duty to Act for Protection of Others: The actor's realization that action on his part is necessary for another's aid or protection does not of itself impose upon him a duty to take such action. ${ }^{6}$

There is no mention of the Ames speech or article in the published volume of the First Restatement and no indication of any serious debate around the issue. Ames was ignored in the First Restatement, but clearly section 314 accurately restated the law as it existed at that time and continues to reflect the common law of Canada and the United States to this day.

Dean William Lloyd Prosser, my beloved teacher and mentor, sometime Dean of the University of California at Berkeley School of Law and later Reporter of the Restatement (Second) of Torts, ${ }^{7}$ declared that the Bad Samaritan no duty rule was "revolting to any moral sense." Because of this, he asserted, many exceptions had developed to the Bad Samaritan rule. In all four editions of his great Hornbook, The Law of Torts, Prosser boldly forecasted that the many extensions to the special relations enabling avoidance of the nonfeasance rule

Francis H Bohlen, “The Moral Duty to Aid Others as a Basis of Tort Liability" (1908) 56:4 U Pa L Rev 217 at 219 \& (1908) 56:5 U Pa L Rev 316.

Ibid at 221.

First Restatement, supra note 3, § 314.

Restatement (Second) of Torts, § 314 (1965) [Second Restatement]. 
that had been developed over the years provided "reason to think" that the courts might approach a general holding, echoing Ames" "working rule," that "mere knowledge of serious peril, threatening death or great bodily harm to another, which [the defendant] might avoid with little inconvenience, creates ... sufficient relation, recognized by every moral and social standard, to impose a duty of action."

Understandably, however, Prosser did not let his personal view, as expressed in his Hornbook, Handbook of the Law of Torts, interfere with his descriptive role as Reporter, so he refrained from substantially altering the no duty rule contained in section 314 of the Second Restatement, despite the increased exceptions that emerged. Hence, his section 314 appeared in almost the same form as in section 314 of the First Restatement:

Duties of Affirmative Action: Duty to Act for Protection of Others: The fact that [an] actor realizes or should realize that action on his part is necessary for another's aid or protection does not of itself impose upon him a duty to take such action. ${ }^{9}$

This same fundamental principle, formulated differently, has now been incorporated into section 37 of the Restatement (Third) of Torts: Liability for Physical and Emotional Harm by the Reporters, Professors Green and Powers, for it still accurately reflects the American common law on the issue:

Affirmative Duties: No Duty of Care With Respect to Risks Not Created by Actor: An actor whose conduct has not created a risk of physical or emotional harm to another has no duty of care to the other unless a court determines that one of the affirmative duties provided in $\S \S 38-44$ is applicable. ${ }^{10}$

This new formulation is more accurate than the one in the first two Restatements. It is blunter and more honest than the two earlier versions, which perhaps hold out the hope that, although realization of danger of itself creates no duty to assist, other unmentioned factors may create that duty. The new version flatly states that no duty exists, unless it is permitted by sections 38 to 44 . It then goes on to enumerate, not significantly differently, the list of situations where a duty of affirmative action will be created: where prior conduct creates a risk of harm; ${ }^{11}$ where there is a special relationship with the other person at risk; ${ }^{12}$ where there is a special relationship with the person posing the risk $;^{13}$ where there is an undertaking that is relied upon or increases the risk; ${ }^{14}$ where there is an undertaking to another person that is relied upon by a third person or increases the risk to that third person; ${ }^{15}$ and where someone takes charge of another who is imperiled and helpless. ${ }^{16}$ One significant addition

William L Prosser, Handbook of the Law of Torts, Hornbook Series (St Paul, Minn: West,1941) at 194; William L Prosser, Handbook of the Law of Torts, 2nd ed, Hornbook Series (St Paul, Minn: West, 1955) at 185; William L Prosser, Law of Torts, 3rd ed, Hornbook Series (St Paul, Minn: West, 1964) at 338-39; W Page Keeton et al, Prosser and Keeton on the Law of Torts, 5th ed, Hornbook Series (St Paul, Minn: West, 1984) at 377.

$9 \quad$ Second Restatement, supra note 7. Note that the words "fact" and "should realize" were added.

10 Restatement (Third) of Torts: Liability for Physical and Emotional Harm, § 37 (2012) [Third Restatement].

Ibid, \& 39.

Ibid, $\$ 40$.

Ibid, $\S 41$.

Ibid, \$ 42 .

Ibid, $\$ 43$.

Ibid, § 44 . 
to the Third Restatement is section 38, a new concept that invites courts, if they so choose, to create a new tort duty by relying on a statute requiring an actor to act for the protection of another. It reads as follows:

Affirmative Duty Based on Statutory Provisions Imposing Obligations to Protect Another: When a statute requires an actor to act for the protection of another, the court may rely on the statute to decide that an affirmative duty exists and to determine the scope of the duty. ${ }^{17}$

This is consistent with the view I advanced in an article in $1966^{18}$ and with Canadian jurisprudence. ${ }^{19}$

These recodified provisions are masterfully organized and formulated. The number of sections utilized has been reduced to seven, from thirteen sections in the First Restatement and ten sections in the Second Restatement. As far as new law is concerned, there has been little movement, except for the new invitation to courts to rely on penal and other statutes to create new tort duties ${ }^{20}$ and the slight lengthening of the list of special relationships importing a duty to act from four (carrier, innkeeper, custodian, and possessor of land) to seven ${ }^{21}$ (adding to the list landlord, employer, and school). Parents, other family members, and companions were sadly not added to the list (although they were discussed as potential future additions) because the jurisprudence did not yet justify their addition. In short, there is still no general duty of easy rescue incorporated into the Third Restatement, because the American common law clearly does not contain such a rule, in spite of Ames' plea and Prosser's forecast. ${ }^{22}$

The Canadian and Commonwealth law is not dissimilar to that of the United States. The fundamental principle is still that there is generally no duty to assist anyone in danger unless there is some recognized relationship between the parties to support that duty. ${ }^{23}$ As Chief Justice McLachlin observed in Childs v. Desormeaux, there is no "free-standing" duty on everyone to become involved in situations where another person faces danger. ${ }^{24}$ In Childs, no liability was imposed on a social host whose former guest at a party drove away inebriated and collided with another vehicle, injuring the plaintiff. The Chief Justice held that

$17 \quad$ Ibid, $\S 38$.

18 AM Linden, "Tort Liability for Criminal Nonfeasance" (1966) 44:1 Can Bar Rev 25 [Linden, "Tort Liability"]. See also Linden \& Feldthusen, supra note 1 at 353. As a member of the Torts Consulting Group of the American Law Institute, I suggested this addition, which the Reporter Michael Green embraced, and the Institute ultimately enacted in ibid, $\S 38$. Lewis Klar was also a member of that group. Linden \& Feldthusen, supra note 1 at 342-53; Horsley et al v MacLaren et al, [1970] 2 OR 487 (CA), aff'd (1971), [1972] SCR 441, Laskin J dissenting [Horsley SCC] (statute found to be a "fortifying element," ibid at 463); Caroline Forell, "Statutes and Torts: Comparing the United States to Australia, Canada, and England" (2000) 36:4 Willamette L Rev 865; contra Lewis N Klar, "Breach of Statute and Tort Law" in Jason W Neyers, Erika Chamberlain \& Stephen GA Pitel, eds, Emerging Issues in Tort Law (Oxford: Hart, 2007).

Third Restatement, supra note $10, \S 38$.

Ibid, $\$ 40$

See Ernest J Weinrib, “The Case for a Duty to Rescue” (1980) 90:2 Yale LJ 247, urging the creation of a duty.

See Linden \& Feldthusen, supra note 1 at 318.

2006 SCC 18, [2006] 1 SCR 643 at 657 [Childs]. See also Klar, Tort Law, supra note 1 at 205; Elizabeth Adjin-Tettey, "Social Host Liability: A Logical Extension of Commercial Host Liability?" (2002) 65:2 Sask L Rev 515; The Honourable Karen M Weiler with the assistance of Laura M Wagner, "Childs v. Desormeaux: Implications for Social Host Liability and for New Torts" (2011) 30:3 Adv J 12 at 12; Lorne Folick, Michael Libby \& Paul Dawson, Liquor and Host Liability Law in Canada (Aurora, Ont: Canada Law Book, 2010). 
merely allowing someone, who later injures someone else, to become drunk at one's home does not create the proximity required to impose a duty. The Chief Justice found that there were three such situations, none of which applied to the social host in the case:

1. where a defendant intentionally attracts and invites people to an inherent and obvious risk he or she created or controls $;^{25}$

2. paternalistic relationships of supervision and control, such as parent-child or teacher-student, because of the vulnerability of the plaintiffs and the position of power of the defendants; ${ }^{26}$ and

3. the exercise of a public function or commercial enterprise that includes implied responsibilities to the public. ${ }^{27}$

Except for Quebec, we Canadians are still a long way from the Ames "working rule" being adopted judicially.

With all due respect, I prefer the structure suggested by Professor Klar in his superb text Tort $\mathrm{Law}^{28}$ to the above list. Professor Klar begins by describing the "strict rule" as follows: "No one doubts the proposition that the modern law of torts imposes no duty to render assistance to those in peril, in the absence of a special relationship, even where assistance can be rendered easily, effectively, and without risk or inconvenience to the rescuer." 29 Professor Klar then proceeds to defend the rule most thoroughly, citing articles and studies, and concludes that "tort law does not, and should not, require individuals to alter the status quo for the benefit of others [for] ... making this conduct tortious is not the appropriate response." ${ }^{30}$ Despite Professor Klar's opposition to a general duty, he fully describes the numerous situations where the status quo is not "alter[ed] ... for the benefit of others" ${ }^{31}$ and where other relations exist such that duties to assist have been imposed: (1) relationships of economic benefit, such as commercial hosts; (2) relationships of control or supervision, such as parents, teachers, employers, carriers, jailers, or police; (3) creators of dangerous situations; (4) reliance situations; (5) statutory duties; and (6) occupiers. ${ }^{32}$ A myriad of cases exist that fit into these categories, demonstrating the willingness of courts to sidestep the socalled "strict rule" where a strong reason to do so exists. Alas, many gaps remain.

While Canadians and Americans resist the idea of Bad Samaritan legislation requiring easy rescue and judges generally resist creating such a law, elsewhere in the world, particularly in Europe, laws requiring easy rescue are commonplace and have been so for over a century. There seems to be no popular or academic pressure in those countries to repeal these laws, despite the occasional difficult issues that arise in the rare situations when they are enforced. More recently, Quebec, Northern Australia, and five American states

Crocker v Sundance Northwest Resorts Ltd, [1988] 1 SCR 1186.

Bain v Board of Education (Calgary) et al (1993), 146 AR 321 (QB).

Jordan House Ltd v Menow, [1974] SCR 239.

Klar, Tort Law, supra note 1 at ch 6.

Ibid at 195 .

Ibid at 197 .

Ibid.

Ibid at $200-26$ 
(Vermont, Rhode Island, Hawaii, Wisconsin, and Minnesota) have enacted general Bad Samaritan laws requiring intervention. ${ }^{33}$ Professor Franklin describes the "boomerang" effect that occurred in Vermont, where doctors sought immunity from liability if they stopped to help people injured in accidents; the doctors received immunity, but the general duty to assist was also imposed on all residents of Vermont, including doctors. ${ }^{34}$ Other states have adopted more limited laws requiring notification to authorities, and sometimes aid, where violent crime or child abuse is observed. ${ }^{35}$

One caring Canadian province, Quebec, has followed the European civil law countries in its Charter of Human Rights and Freedoms, which has quasi-constitutional status. Section 2 reads as follows:

Right to assistance. Every human being whose life is in peril has a right to assistance.

Aiding person whose life is in peril. Every person must come to the aid of anyone whose life is in peril, either personally or calling for aid, by giving him the necessary and immediate physical assistance, unless it involves danger to himself or a third person, or he has another valid reason. ${ }^{36}$

Quebec is a province that cares deeply about the safety of its people and is ready to constitutionally protect them in many ways, including by requiring fellow citizens to assist in times of danger in the spirit of fraternité. ${ }^{37}$

Years ago, when I was president of the Law Reform Commission of Canada, we recommended an amendment to the Canadian Criminal Code, ${ }^{38}$ reflecting this humane approach of Quebec, as follows:

Failure to Rescue: "[E]veryone commits a crime who fails to take reasonable steps to assist another person whom he sees in instant and overwhelming danger."

Exception: "[U]nless he is incapable of doing so without serious risk to himself or another or there is some other valid reason for not giving assistance."

Alas, this sensible provision has not yet been enshrined in the Criminal Code by the Parliament of Canada, much to my disappointment. ${ }^{39}$

These penal Bad Samaritan laws impose a modest criminal sanction on a person who is present and realizes that another person is in serious peril for failure to assist when assistance can be given without inconvenience or harm to the person. In the civilian jurisprudence, it Williams U L Rev 77.

Marc A Franklin, "Vermont Requires Rescue: A Comment" (1972) 25:1 Stan L Rev 51 at 53ff.

See Marc A Franklin \& Matthew Ploeger, "Of Rescue and Report: Should Tort Law Impose a Duty to Help Endangered Persons or Abused Children?" (2000) 40:4 Santa Clara L Rev 991 for an excellent survey opposing a general civil duty.

Charter of Human Rights and Freedoms, CQLR c C-12, s 2.

See Gaudreault c Drapeau (1987), 45 CCLT 202 (Que SC).

RSC 1985, c C-46.

Allen M Linden et al, "Omissions, Negligence and Endangering" (1995) Law Reform Commission of Canada Working Paper 46. 
is common for the violation of a penal statute to be treated as a "fault," producing civil liability as well as criminal, but the civilian legislation does not normally provide expressly for civil liability. The American states that have enacted these laws generally provide only for modest penal sanctions, which may or may not influence the creation of a civil duty as well. ${ }^{40} \mathrm{We}$ do not yet know whether, when, or where section 38 will influence the jurisprudence of those states that have adopted Bad Samaritan laws. In fact, one American state, Hawaii, specifically enacted that a person who fails to provide reasonable assistance, as required by its penal law in this regard, will not be liable for any civil damages. ${ }^{41}$

Whereas Bad Samaritan laws have not been widely embraced in the United States, Good Samaritan laws - compromise measures that provide full or partial immunity to those who assist unless they are grossly negligent - have been enacted in almost all states and Canadian provinces. ${ }^{42}$ The idea, apparently, is that the "carrot" of immunity for Good Samaritans is a more palatable incentive for altruism than the "stick" of penal and civil liability for Bad Samaritans, which is regarded as overly intrusive and difficult to administer.

It is difficult for me to understand why, despite more than a century of condemnation of tort law's treatment of Bad Samaritans by judges, academics, and other writers, the United States and Canada have generally resisted following the civil law tradition by mandating easy rescue. The overwhelming majority of writers paint the current law as monstrous, callous, and revolting, and as "a stain on the law," but American and Canadian legislatures and courts have nevertheless withstood the pressure to change as Ames, Prosser, and many others have urged. ${ }^{43}$ This neglect is particularly incomprehensible in an age when everyone carries a cell phone and can call for help without any risk whatsoever to him- or herself.

The many incidents of failure to assist publicized over the years - Kitty Genovese (1964), the Billiard Table Rape in the New Bedford Massachusetts Bar (1983), Princess Diana's death (1997), the rape and killing of Sherrice Iverson in a Nevada casino (1998), the computer suicide case (2008), and others - enrage editorial writers. However, with few exceptions, courts and legislatures do not heed their calls for reform. The final Seinfeld television episode ${ }^{44}$ featuring a criminal trial in which the Seinfeld gang was charged with failing to assist during a crime of robbery, as required by Vermont law, did not help the cause at all.

Our legal treatment of the Bad Samaritan shames the common law. Everyone recognizes this. Yet, usually embarrassingly and apologetically, the nonfeasance rule is defended by uncharacteristically timid scholars for various reasons. Procedural and administrative reasons

Marshall S Shapo, The Duty to Act: Tort Law, Power \& Public Policy (Austin: University of Texas Press, 1977); Marshall S Shapo, Basic Principles of Tort Law, Hornbook Series (St Paul, Minn: West Group, 1998) at 300; Weinrib, supra note 22; Linden, "Tort Liability," supra note 18; Allen Linden, "Rescuers and Good Samaritans" (1971) 34:3 Mod L Rev 241; James M Ratcliffe, ed, The Good Samaritan and the Law (New York: Anchor Books, 1966); Robert M Ackerman, "Tort Law and Communitarianism: Where Rights Meet Responsibilities" (1995) 30:4 Wake Forest L Rev 649; Wallace M Rudolph, "The Duty to Act: A Proposed Rule" (1965) 44:3 Neb L Rev 499.

Third Restatement, supra note $10, \S 38$.

Schiff, supra note 33 .

See e.g. Alberta, Emergency Medical Aid Act, RSA 2000, c E-7; Good Samaritan Act, 2001, SO 2001, Seinfeld "The Finale," 1998, DVD (Culver City: Sony Pictures Home Entertainment, 2013). 
are often advanced. ${ }^{45}$ Fear of interference with individual autonomy and placing undue burdens on ordinary people to aid strangers is also a source of worry. Some writers are concerned with the danger posed by poor quality rescues and the risk to untrained rescuers themselves. ${ }^{46}$ As for the risk to potential rescuers, the available and omnipotent cell phone virtually removes any necessary risk to those who wish to help by merely making a telephone call to police or firemen. Some warn about the danger of discouraging cooperation with law enforcement and potential deterrence of delayed rescue is also mentioned. ${ }^{47}$ Others bemoan the discounting of altruism. ${ }^{48}$ There is also the contention that a Bad Samaritan law is unnecessary because the incentives we already have in place - compensation for injured rescuers, crime victim compensation, media praise, frequent voluntary financial rewards, religious and moral teaching, and immunity from liability — are sufficient to encourage most Canadians and Americans to "step up" when needed. ${ }^{49}$ If more encouragement is wanted, it is suggested, additional incentives should be added rather than penal or civil sanctions. ${ }^{50}$ This is a long list of concerns about reform, but it is unconvincing to me.

The list of reasons to adopt a general affirmative duty to rescue is less lengthy but more compelling. The argument here is grounded largely in values, for there is no guarantee that Bad Samaritan laws will produce a flurry of additional rescue efforts. My main plea here is that we torts people should, in our circumscribed but significant domain, ensure that our tort law reflects the best in our culture, the decency and humanitarianism that is the hallmark of English-speaking peoples, not our selfishness. The attention that our tort law showers on those injured tortiously is noble, indeed legendary, and perhaps occasionally even overdone. In the past, the US and common law tort system was a beacon for the world, beckoning other countries to emulate us and provide just, even generous, civil redress to victims of tortious conduct.

It was this incandescent beacon that drew me, a young law graduate from Osgoode Hall Law School, to Berkeley in 1960 to study US tort law with the great Dean William Lloyd Prosser. Soon after, it was this beacon that ensnared me in thalidomide litigation when the Canadian law firm that sought my opinion about whether an action might succeed decided, against my advice, that it would not represent a family of thalidomide survivors seeking to retain the firm. The senior partner privately told me: "This firm is not a charitable organization." Doubting success and fearing the enormous cost and effort involved, the firm handed me the file, saying that I was welcome to launch a claim myself, if I believed one might succeed. Realizing the insurmountable odds against such a claim succeeding in Canada at that time, I lay awake that night pondering the options, until I had an epiphany. The next morning, I approached American legal counsel, who bravely undertook the challenge, suing in the US. Eventually, after more than a decade, fair settlements for the thalidomide family with whom I was involved, as well as for the families of some other Canadian children, were achieved. Whereas the Canadian legal system failed to act as a Good Samaritan to help these

45 James A Henderson Jr, "Process Constraints in Tort" (1983) 67:5 Cornell L Rev 901.

46 Indeed, some rescuers lose their lives in their heroic but futile efforts: Horsley SCC, supra note 19.

Ibid.

Marin Roger Scordato, "Understanding the Absence of a Duty to Reasonably Rescue in American Tort Law" (2008) 82:4 Tul L Rev 1447. See also Anthony D’Amato, “The 'Bad Samaritan' Paradigm" (1976) 70:5 Nw UL Rev 798.

49 David A Hyman, "Rescue Without Law: An Empirical Perspective on the Duty to Rescue" (2006) 84:3 Tex L Rev 653.

Franklin \& Ploeger, supra note 35. 
Canadian families, the US system, to its credit, did not walk by but came to their rescue as the Good Samaritan once did. Many years later, after the tort settlement money was exhausted, another public campaign became necessary and was launched on behalf of the 94 Canadian thalidomide survivors, led by Stephen Raynes of Philadelphia and The Globe and Mail, which culminated in an ex gratia settlement this year, following the unanimous resolution by Parliament on 1 December 2014. ${ }^{51}$

But "you can't be a beacon if your light don't shine." 52 That light has been dimmed in recent years by the sometimes exorbitant awards, occasional ruthless defence conduct, delays, enormous legal and expert costs, occasional fraudulent claims, and unethical lawyers. The tort reform movement in the US and, to a lesser extent, in Canada has addressed some of these warts on torts, causing a marked retreat in the development of tort law, perhaps weakening it and improving it in some ways. But the American Tort Reform Association has not targeted the Bad Samaritan rule, which also fuels the negative reputation of tort law, both domestically and internationally. Strangely, in this area it is the foreign law and that of heroic Quebec and the five US states that have become the light shining on the common law countries, beckoning us to follow their lead. ${ }^{53}$

In the past, tort law's concern for injured neighbours has often extended beyond those hurt by positive conduct and included, in many situations, those hurt by inaction or failure to act where injury could have been avoided or minimized. In the landmark case Donoghue v. Stevenson, the UK House of Lords espoused the neighbour principle as follows:

\footnotetext{
The rule that you are to love your neighbour becomes in law, you must not injure your neighbour; and the lawyer's question, Who is my neighbour? receives a restricted reply. You must take reasonable care to avoid acts or omissions which you can reasonably foresee would be likely to injure your neighbour. Who, then, in law is my neighbour? The answer seems to be - persons who are so closely and directly affected by my act that I ought reasonably to have them in contemplation as being so affected when I am directing my mind to the acts or omissions which are called in question. ${ }^{54}$
}

Note that either "acts or omissions" can lead to liability for damage to a neighbour. Justice Idington of the Supreme Court of Canada once complained about the "deeply rooted" distinction expounded by Professor Bohlen between misfeasance and nonfeasance. ${ }^{55}$ Justice Idington wrote: "The sooner the distinction between nonfeasance and misfeasance ... is discarded, the better." ${ }^{56}$ The gulf between nonfeasance and misfeasance is not and should not be as deeply rooted and immutable as Bohlen proclaimed.

Steven Chase \& Ingrid Peritz, "Parliamentary motion for 'full support' for thalidomide survivors passes unanimously," The Globe and Mail (1 December 2014), online: <www.theglobeandmail.com/news/ politics/thalidomide-survivors-set-deadline-for-federal-response-on-support/article21860466/>.

Donna Fargo, "You Can't Be a Beacon (If Your Light Don't Shine)," CD: Miss Donna Fargo (Dot Records, 1974).

The Honourable Allen Linden, “American Tort Law: Shining Beacon?” (2011) 38:2 Pepp L Rev 215. [1932] AC 562 at 580.

Bohlen, supra note 4 at 219 .

Vancouver (City of) v McPhalen (1911), 45 SCR 194 at 207-208. See also Clarence Morris, Studies in the Law of Torts (Brooklyn: Foundation Press, 1952). 
My main focus here is the educational, didactic, or "expressive" function of tort law, ${ }^{57}$ though not diminishing, its compensatory and deterrent roles. Tort law, like all law, teaches; it influences attitudes in law-abiding citizens about right and wrong. That is a primary function of criminal law, human rights law, and constitutional law. Characteristically, our law supports those who do the right thing and denounces those who do the wrong thing. When our tort law, by not denouncing Bad Samaritans, declares that one need not assist someone in danger, it impoverishes the moral stature of that law, both at home and abroad.

It may have been acceptable to walk by when the "Yankee from Olympus," Justice Oliver Wendell Holmes, wrote years ago, "I see no right in my neighbor to share my bread," 58 but that view is unacceptable today. The Canadian government is finally compensating our First Nations people for their suffering in the residential schools. We have set up a fund for our thalidomide victims after half a century of neglect. The US government created the 9/11 compensation plan to assist the families of those killed. BP Oil was required to compensate for losses caused by its huge oil spill in the Gulf of Mexico. The world is finally responding to the many recent refugee disasters. Civilized societies now mandate some sharing of our wealth with our neighbours through taxes, social legislation, and many other programs benefiting the less fortunate. Unlike the denial uttered by Cain, who had killed his brother Abel, we should embrace the role of being our "brothers' keepers," at least to some extent.

I hope that these examples will promote a spirit of renewal that will infiltrate the law of torts, restore its concern for the underdog, stem its retreat from the neighbour principle, foster feelings of sharing and community, and, finally, bring to fruition the dreams of Ames, Prosser, and others about our treatment of the Bad Samaritan. We need not deny that this would be "largely symbolic," setting a "moral standard for society," as the sponsor of the Minnesota bill confided. ${ }^{59}$ That is the main purpose for holding Bad Samaritans liable in tort.

The administrative and procedural arguments against the Bad Samaritan law are not convincing. Of course there are problems administering law that must be considered before enacting new laws. But when a law is thought to be necessary or desirable, we promulgate it and do our best to administer it fairly and efficiently. Tort law, with its requirements of proof of unreasonable conduct and causation, often with a jury, is sometimes difficult, costly, and slow to administer. We are miraculously able to handle billion-dollar class action tort suits. Luckily, most claims settle or the system would break down, as some say it already has. I am confident that we can administer Bad Samaritan laws reasonably well, if we choose to do so. There will be thorny issues, ${ }^{60}$ but there always are. If we decide to adopt a Bad Samaritan law, we will be able to sort these issues out.

The concerns about potentially crushing liability for bystanders cannot be ignored, but this would be a rare occurrence. ${ }^{61}$ People rescued would rarely sue their rescuers, even if they did and the Living Constitution (New York: NYU Press, 1993) at 7.

59 Sungeeta Jain, "How Many People Does it Take to Save a Drowning Baby?: A Good Samaritan Statute in Washington State" (1999) 74:4 Wash L Rev 1181 at 1192. 
not perform perfectly. Nor would they sue those who fail to rescue them altogether, at least if there is no insurance. However, as one California case demonstrates, this does happen. ${ }^{62}$ The defendant came to the aid of her friend after a car crash and removed her from the vehicle because she said she feared the car might "blow up." In doing so, it was alleged that she caused the plaintiff to become paralyzed because she "yanked" her out "like a rag doll." In a motion for summary judgment based on section 1799 of the California Good Samaritan law protecting those who provide medical care, the Supreme Court of California held 4-3 not to immunize the defendant, whose aid was not held to be "medical." ${ }^{3}$ The California Assembly has wisely enacted amendments to excuse Good Samaritans who offer both medical and non-medical help, unless there is gross negligence or misconduct. ${ }^{64}$

\section{CONCLUSION}

After more than 100 years of debate, I hope that the common law of torts and legislatures will begin, in the years ahead, to move beyond the First Restatement, Second Restatement, and Third Restatement in the direction suggested by Ames, Prosser, and others. Perhaps the legislative bodies of more jurisdictions, in a new spirit of caring, will adopt legislation penalizing Bad Samaritans, as Quebec and other jurisdictions have done, mandating a general duty of easy rescue. Perhaps more jurisdictions, like several have already done, will adopt specific laws that focus only on reporting of crimes and child abuse on pain of penal liability. Maybe those places will eventually expand their specific laws to encompass other (or eventually all) situations of physical peril, as they realize that the potential negative effects of these laws are less than feared. Some of these areas may expressly immunize from civil liability those who assist when required to do so, as Hawaii has done. ${ }^{65}$ Some may impose civil liability instead of penal responsibility or in addition to penal responsibility. Others may leave open the issue of civil liability, allowing the courts to decide whether to create a civil duty consistent with section $38{ }^{66}$ A comprehensive draft of possible legislation is proposed by Professor Schiff. ${ }^{67}$

The common law of torts is not without the capacity to develop, as it has shown in so many ways over the centuries. Perhaps it would be preferable in some jurisdictions for legislatures to lead here, as some already have. Perhaps a measure containing a minor penalty is less risky than full tort liability, at least as a start. But tort law does not have to behave as a Bad Samaritan and walk by. Some courts, moved by a new humanitarian spirit, could adopt the proposed rule of Ames and Prosser without any direction from their legislatures, as US courts did with strict products liability and so many other areas. ${ }^{68}$

Compare also 911 case finding immunity, Eastburn v Regional Fire Protection Authority, 7 Cal Rptr 3d 522 (Cal 2003).

64 Heather Antonie \& Jeff Diamond, "To Assist or Not to Assist?: Still the Question, as California's Legislative Response to Van Horn v. Watson Provides Inadequate Guidance to Good Samaritans" (2009) 37:1 W St U L Rev 85.

Hawaii Revised Statutes, 4 HRS tit 36 \& 663-1.6 (2015).

JS $v$ RTH, 714 A (2d) 924 (NJ 1998). Cf Perry v SN and SN, 973 SW 2d 301 (Tex 1998).

Schiff, supra note 33 .

See generally, G Edward White, Tort Law in America: An Intellectual History, expanded ed (New York: Oxford University Press, 2003). 
Another promising possibility is the imaginative yet sensible proposal of Professor Adler, based on the Wisconsin Supreme Court decision Schuster v. Altenberg ${ }^{69}$ and the California decision Rowland v. Christian, ${ }^{70}$ who suggests that courts should "require reasonable efforts to aid or protect others absent overriding competing societal interests." ${ }^{71}$ Professor Adler argues that juries should be allowed to consider the reasonableness of injury-causing behaviour, even if it could be characterized as nonfeasance. ${ }^{72}$ In other words, the ordinary duty analysis of tort law should be employed by courts in these cases, without being blinded by our obsession with the misfeasance-nonfeasance dichotomy so powerfully advocated by Professor Bohlen over 100 years ago. Professor Adler suggests that this approach would "turn the traditional rules on their head" replacing the no-duty rule with a "presumption that reasonable conduct is required unless one or more policy concerns mandate a deviation from the norm." ${ }^{\text {73 }}$ Actually, this suggestion is less dramatic than it seems: it merely seeks to apply the Third Restatement's general duty rule to nonfeasance situations in the same way it is applied to positive conduct. ${ }^{74}$ Remember that the general duty rule is to be generally utilized; departures from it are "exceptional" and only justified where special problems of "principle or policy [warrants] denying or limiting liability." "75 It might even be argued that not to assist is not "inaction" at all but rather an "action," that is, the act of deciding followed by the "act of refraining to act." Unfortunately, heretofore mesmerized by Professor Bohlen and a fear of the unknown, most common law courts have treated nonfeasance situations as "exceptional," something Professor Adler and I wish to alter.

In concluding these perhaps overly romantic musings of an aging tortaholic, I cannot help but add my voice to those who, for over a century, have called for a new approach to dealing with Bad Samaritans. This is done not only for its potential utility in saving lives and providing compensation, but also for its symbolic significance to my beloved tort law and its humane future contribution in this increasingly uncaring world. As a sentinel of safety, tort law should demonstrate that it cares, that it really cares about fraternité as well as about fairly determining fault. My fervent wish is that, in the coming years, the "working rule" of Dean Ames and Dean Prosser's forecast, or some version of it, will finally be enshrined judicially or legislatively throughout the common law world so that on this topic, as on so many others, tort law will become a badge of pride both nationally and internationally, rather than a source of shame. Tort law should hasten its development toward liability for Bad Samaritans, Professor Lewis Klar notwithstanding. ${ }^{76}$

424 NW (2d) 159 (Wis 1988).

443 P (2d) 561 (Cal 1968).

John M Adler, "Relying upon the Reasonableness of Strangers: Some Observations about the Current State of Common Law Affirmative Duties to Aid or Protect Others" (1991) 1991:5 Wis L Rev 867 at 901.

Ibid at 901.

Ibid at 904-905.

In the Canadian context, the situation is more complex because of the analysis in Cooper v Hobart, [2001] 3 SCR 537.

Third Restatement, supra note $10, \S 7$.

I say this respectfully and lovingly. 